\title{
Evaluasi Keandalan Jembatan Gantung Pejalan Kaki Dengan Variasi Letak dan Jenis Beban Lalu Lintas
}

\author{
Euneke Widyaningsih \\ Institut Teknologi Nasional, Bandung, Indonesia \\ Email: eunekewidya@itenas.ac.id
}

Received 30 April 2020 | Revised 02 Juli 2020 | Accepted 03 Juli 2020

\begin{abstract}
ABSTRAK
Untuk mendukung pembangunan infrastruktur jembatan, pemerintah mengeluarkan panduan untuk perencanaan jembatan gantung dengan judul Surat Edaran Menteri Pekerjaan Umum No. 02/SE/M/2010 tentang Pemberlakukan Pedoman Perencanaan dan Pelaksanaan Konstruksi Jembatan Gantung Untuk Pejalan Kaki. Jembatan gantung yang dirancang sesuai dengan panduan tersebut harus mampu menahan beban pejalan kaki sebesar $5 \mathrm{kPa}$. Dengan mengacu pada pedoman tersebut, direncanakanlah sebuah jembatan gantung dengan panjang total 127.34 meter. Agar dapat mengetahui perilaku jembatan terhadap beban yang direncanakan, dibuatlah pemodelan jembatan menggunakan software MidasCIVIL dengan menggunakan 4 variasi letak pembebanan dan 80 variasi beban mewakili bobot pejalan kaki dan kendaraan bermotor roda dua. Tujuan dilakukannya analisis ini adalah untuk mengetahui nilai keandalan struktur yang direncanakan dengan beban sesuai Surat Edaran Menteri Pekerjaan Umum No. 02/SE/M/2010 terhadap variasi beban pejalan kaki dan kendaraan bermotor yang sesungguhnya mungkin terjadi pada jembatan. Evaluasi struktur menggunakan metode probability based menghasilkan keandalan struktur jembatan sebesar 100\% yang dianalisis terhadap lendutan, tegangan kabel, tegangan batang penggantung serta tegangan pilar. Sehingga dapat dikatakan bahwa beban $5 \mathrm{kPa}$ yang disyaratkan oleh pedoman memiliki nilai yang konservatif dan akan menghasilkan struktur jembatan yang sangat aman.
\end{abstract}

Kata kunci: : Jembatan Gantung, Variasi Letak Beban, Pejalan Kaki, Probability Based Design

\begin{abstract}
To support the establishment of bridge infrastructure, the government issued a guide for planning a suspension bridge with the title Surat Edaran Menteri Pekerjaan Umum No. 02 / SE / M / 2010 concerning the Implementation of Guidelines for Planning and Construction of Suspension Bridges for Pedestrians. Suspension bridges designed according to these guidelines must be able to withstand pedestrian loads of $5 \mathrm{kPa}$. With reference to these guidelines, a suspension bridge is planned with a total length of 127.34 meters. In order to know the bridge's behavior towards the planned load, a bridge modeling was made using MidasCIVIL using 4 position of loading and 80 load variations representing pedestrian weight and two-wheeled motorized vehicles. The purpose of this analysis is to determine the value of the bridge reliability that planned with load according to the Surat Edaran Menteri Pekerjaan Umum No. 02 / SE / M / 2010 against variations in pedestrian and motor vehicle loads that might actually occur on bridges. Structural evaluation using probability-based methods produces $100 \%$ bridge structure reliability which is analyzed for deflection, cable stress, hanger stress and pillar stress. So, it can be said that the $5 \mathrm{kPa}$ load required by the guidelines has a conservative value and will produce a very safe bridge structure.
\end{abstract}

Keywords: Suspension Bridge, Load Position Variation, Pedestrian, Probability Based Design 


\section{PENDAHULUAN}

\subsection{Latar Belakang}

Menilik kondisi penggunaan jembatan di berbagai wilayah di Indonesia, terutama di pedesaan, jembatan gantung harus diperhatikan agar mampu menahan beban pejalan kaki serta beban kendaraan bermotor roda dua. Desain dan pembebanan jembatan gantung untuk pejalan kaki dirangkum dalam panduan untuk perencanaan dan pelaksanaan dari Surat Edaran Menteri Pekerjaan Umum No. 02/SE/M/2010. Pembebanan dari Surat Edaran tersebut tidak secara spesifik menyatakan beban lalu lintas apa saja yang dapat diberikan pada jembatan gantung. Pada dasarnya, variasi beban yang dapat terjadi saat jembatan beroperasi bukan hanya berasal dari pejalan kaki saja. Kondisi beban lalu lintas pejalan kaki dan kendaraan bermotor pada suatu jembatan memiliki variasi yang tak berhingga. Mulai dari variasi posisi beban, variasi tipe motor, variasi berat motor, variasi muatan motor, variasi berat pejalan kaki, dan lain sebagainya.

Jembatan dengan bentuk jembatan gantung terdiri atas beberapa elemen struktural. Elemen yang terdapat pada jembatan gantung diantaranya adalah pelat lantai, gelagar melintang, gelagar memanjang, batang penggantung, kabel dan pilar jembatan. Dari berbagai elemen struktural yang membentuk jembatan, komponen utama yang perlu diperhatikan yaitu elemen batang penggantung, kabel dan pilar jembatan. Oleh sebab itu, evaluasi yang akan dilakukan terhadap keandalan jembatan ditinjau pada ketiga elemen tersebut terhadap berbagai variasi beban. Salah satu cara yang dapat digunakan untuk memperoleh nilai keandalan suatu struktur adalah dengan menghitung nilai peluang gagal (probability of failure).

Tujuan dari dilakukannya penelitian ini adalah untuk mengetahui perilaku struktur jembatan yang direncanakan mengacu pada Surat Edaran Menteri Pekerjaan Umum No. 02/SE/M/2010 terhadap beban pejalan kaki dan kendaraan bermotor roda dua yang divariasikan menurut kondisi aktual serta untuk mengetahui nilai keandalan struktur dari jembatan gantung pejalan kaki terhadap variasi beban pejalan kaki dan kendaraan bermotor aktual.

\subsection{Jembatan Gantung}

Jembatan gantung adalah jembatan yang pelat lantai nya digantung pada kabel menggunakan batangbatang penggantung vertikal. Sistem ini akan menyalurkan beban yang diterima oleh pelat lantai menjadi tegangan pada kabel utama sehingga ujung-ujung kabel utama ini harus di angkur pada tanah keras [3]. Kabel utama pada sistem jembatan ini digantung di antara dua pilar kemudian menerus ke belakang masing-masing pilar sampai ketinggian sejajar dengan pelat lantai dan diangkur untuk menyalurkan tegangan kabel akibat beban pada angkur kemudian pada tanah.

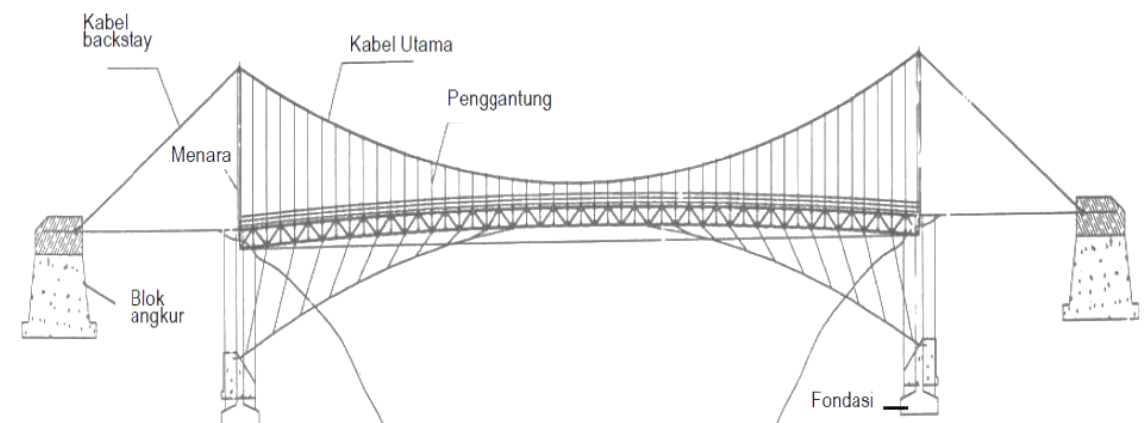

Gambar 1. Skema Jembatan Gantung dan Bagiannya [4]

Elemen struktural utama pada jembatan gantung yang berfungsi menahan sekaligus menyalurkan beban-beban adalah elemen kabel jembatan. Gaya tarik kabel dihitung dari proyeksi akan gaya-gaya horizontal akibat beban jembatan. Gaya horizontal pada ujung kabel utama dihitung dengan rumus:

- $\quad$ Untuk beban hidup merata

$$
H_{1}=\frac{P L^{2}}{8 d}
$$


- Untuk beban hidup asimetris hanya bekerja di $1 \frac{1}{2}$ bentang

- Untuk berat sendiri jembatan

$$
\begin{aligned}
& H_{2}=\frac{\left(\frac{P}{2}\right) L^{2}}{8 d} \\
& H_{a}=\frac{w L^{2}}{8 d}
\end{aligned}
$$

Kemudian komponen horizontal gaya tarik ini diproyeksikan pada arah kabel terhadap sumbu horizontal.

$$
T=\frac{H}{\cos \theta}
$$

\subsection{Pembebanan Jembatan Pejalan Kaki}

Jembatan pejalan kaki harus kuat dan kaku (tanpa lendutan yang berlebih) untuk menahan berat sendiri jembatan, beban mati tambahan dan beban hidup rencana yang bekerja pada arah vertikal. Selain itu jembatan gantung pejalan kaki juga harus mampu menahan beban yang terjadi pada arah horizontal yang diakibatkan oleh tekanan angin, gempa, pengguna yang bersandar dan benturan akibat barang-barang yang terbawa oleh arus sungai. [5]

Dalam hal pembebanan yang berasal dari beban hidup atau pengguna jembatan dibedakan berdasarkan kelas jembatan yang direncanakan. Selain dari kelas jembatan, ada dua aspek dari beban hidup pada jembatan gantung yang harus diperhatikan yaitu beban terpusat pada lantai jembatan jembatan akibat langkah kaki manusia untuk memeriksa kekuatan lantai jembatan dan beban yang dipindahkan dari lantai jembatan ke batang struktur yang kemudian dipindahkan ke tumpuan jembatan.

Untuk nilai dari beban-beban hidup rencana dapat dilihat pada Tabel 1 di bawah ini:

Tabel 1. Kelas Jembatan [2]

\begin{tabular}{lccc}
\hline Kelas Pengguna & Lebar & Beban Terpusat & $\begin{array}{c}\text { Beban Terdistribusi } \\
\text { Merata }\end{array}$ \\
\hline $\begin{array}{l}\text { Jembatan gantung pejalan } \\
\text { kaki kelas I (beban hidup } \\
\text { maksimum sampai }\end{array}$ & $1.8 \mathrm{~m}$ & $\begin{array}{c}20 \mathrm{kN} \text { (hanya ada satu } \\
\text { kendaraan bermotor } \\
\text { ringan pada satu waktu } \\
\text { tengan kendaraantu) }\end{array}$ & $500 \mathrm{~kg} / \mathrm{m}^{2}$ \\
\hline $\begin{array}{l}\text { Jembatan gantung pejalan } \\
\text { kaki kelas II (beban hidup } \\
\text { dibatasi hanya untuk } \\
\text { pejalan kaki dan sepeda } \\
\text { motor) }\end{array}$ & $1.4 \mathrm{~m}$ & $400 \mathrm{~kg} / \mathrm{m}^{2}$ \\
\hline Keterangan: L adalah bentang utama jembatan & & \\
\hline
\end{tabular}

\subsection{Probabilitas Struktur}

Probabilitas atau peluang adalah suatu angka yang menunjukkan kemungkinan terjadinya suatu kejadian. Nilai probabilitas suatu kejadian berada di antara 0 sampai 1, dimana nilai 0 menunjukkan ketidakpastian dan nilai 1 menunjukkan kepastian [1].

Pada pendekatan struktur bangunan, biasanya nilai probabilitas kegagalan struktur dibatasi oleh nilai tahanan struktur dan beban yang diterima strukur. Telah diketahui bahwa untuk mencapai struktur yang aman nilai tahanan harus selalu lebih besar dibandingkan dengan nilai beban. 


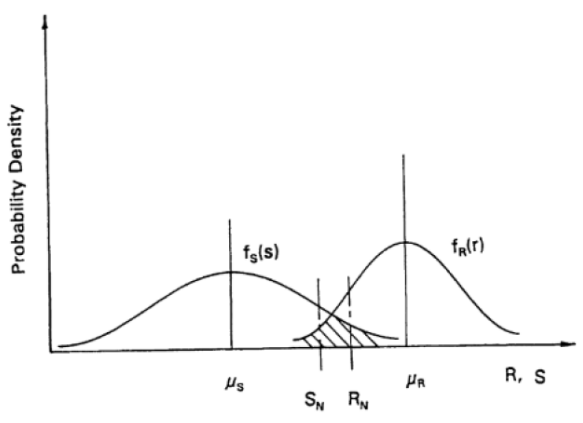

Gambar 2. Probabilitas Kegagalan Struktur

Probabilitas kegagalan struktur dipengaruhi oleh beberapa faktor pada fungsi tahanan dan fungsi beban yaitu: nilai rata-rata $(\mu)$, standar deviasi $(\sigma)$ dan koefisien variasi $(\Omega)$. Nilai rata-rata adalah nilai yang merupakan total nilai-nilai pada suatu fungsi dengan variabel acak yang dibagi dengan jumlah nilai yang terlibat dalam perhitungan tersebut. Standar deviasi adalah ukuran yang menunjukkan bagaimana nilai-nilai data tersebar. Sementara koefisien variasi adalah suatu perbandingan antara standar deviasi dengan nilai rata-rata yang dinyatakan dengan persentase.

Selain ketiga faktor di atas, suatu fungsi variabel acak juga memiliki berbagai tipe distribusi. Beberapa istilah fungsi distribusi yang paling umum dikenal adalah distribusi normal dan distribusi log-normal.

\subsection{Keandalan Struktur}

Secara konvensional, keberhasilan suatu struktur dinyatakan apabila kondisi terburuk dari struktur (kapasitas minimum struktur) masih dapat menahan kondisi beban terburuk yang diberikan (beban maksimum). Namun, dengan tahanan dan beban yang berbentuk fungsi distribusi dari variabelvariabel acak, prinsip ini tidak bisa mempertimbangkan ketidakpastian yang terjadi baik pada fungsi tahanan maupun pada fungsi beban. Oleh sebab itu perlulah tahanan dan beban ini dinyatakan dalam suatu fungsi yang dimodelkan dengan variabel-variabel acak.

Jika dimisalkan $X$ sebagai kapasitas struktur dan $Y$ sebagai beban yang direncanakan, maka struktur akan dikatakan aman apabila $(X>Y)$ sehingga peluang struktur ini handal dalam menahan beban dapat dinyatakan dalam $P(X>Y)$. Kebalikannya, jika struktur tidak mampu lagi menahan beban, maka fungsi persamaan menjadi $P(X<Y)$. Fungsi ini dikenal dengan peluang kegagalan atau Probability of Failure $\left(P_{F}\right)$.

Untuk menghitung nilai peluang kegagalan, dapat dilakukan dengan 2 cara.

1. Margin of Safety

$X<Y \rightarrow X-Y<0$

Jika $X-Y=M$ maka kegagalan akan terjadi apabila $M<0$

Pada kasus ini peluang kegagalan menjadi:

$P_{F}=\int_{-\infty}^{0} f_{M}(m) d m=F_{M}(0)$

Cara ini digunakan untuk perhitungan reabilitas untuk persamaan dengan distribusi fungsi normal.

2. The Factor of Safety

$X<Y \rightarrow \frac{X}{Y}<1$

Jika $X / Y=\theta$ maka kegagalan akan terjadi apabila $\theta<1$

Pada kasus ini peluang kegagalan menjadi:

$$
P_{F}=\int_{0}^{1} f_{\theta}(\theta) d \theta=F_{\theta}(1.0)
$$


Cara ini digunakan untuk perhitungan reabilitas untuk persamaan dengan distribusi fungsi log-normal.

\section{METODOLOGI}

Penelitian ini dimulai dengan melakukan desain struktur jembatan gantung dengan menggunakan acuan pembebanan dari Surat Edaran Menteri Pekerjaan Umum No. 02/SE/M/2010 tentang Pemberlakukan Pedoman Perencanaan dan Pelaksanaan Konstruksi Jembatan Gantung Untuk Pejalan Kaki. Selanjutnya dilakukan analisis perilaku jembatan terhadap beban pejalan kaki dan kendaraan yang berjalan melintasinya dengan 4 variasi letak pembebanan dan 80 variasi beban yang akan menghasilkan nilai probabilitas kegagalan struktur jembatan terhadap variasi beban yang telah dibuat.

\subsection{Desain Elemen Jembatan}

Perencanaan dimensi jembatan dilakukan untuk masing-masing elemen. Dimulai dari elemen pelat lantai, elemen balok memanjang dan melintang, elemen hanger, elemen kabel dan terakhir elemen pilar jembatan. Perhitungan ini mempertimbangan tegangan leleh material jembatan yang dibandingkan dengan beban rencana yang diterima oleh jembatan. Luaran dari tahapan ini adalah dimensi elemen-elemen jembatan gantung yang digunakan dalam pemodelan jembatan keseluruhan untuk pengecekan syarat kekuatan dan lendutan struktur jembatan secara global.

Elemen jembatan direncanakan menahan beban sebesar $5 \mathrm{kPa}$ sesuai dengan panduan yang berlaku. Dimensi elemen jembatan yang diperoleh dapat dilihat pada tabel 2 di bawah ini:

Tabel 2. Dimensi Elemen Jembatan

\begin{tabular}{lll}
\hline Nama Elemen Jembatan & $\begin{array}{l}\text { Material yang } \\
\text { Digunakan }\end{array}$ & Dimensi yang Digunakan \\
\hline Pelat & Kayu LVL & $300 \mathrm{~mm} \times 50 \mathrm{~mm}$ \\
\hline Gelagar Memanjang & Kayu LVL & $150 \mathrm{~mm} \times 75 \mathrm{~mm}$ \\
\hline Gelagar Melintang & Kayu LVL & $150 \mathrm{~mm} \times 75 \mathrm{~mm}$ \\
\hline Batang Penggantung & Baja BJ41 & $10 \mathrm{~mm}$ \\
\hline Kabel & Kabel Baja ASTM A416 & $\begin{array}{l}\text { kawat untaian 7 wire-strand } \\
\text { diameter 12.7mm }\end{array}$ \\
\hline Pilar & Grade 270 & IWF 300.300.10.15 \\
\hline
\end{tabular}

\subsection{Pemodelan Jembatan}

Dimensi struktur yang telah diperoleh dalam perencanaan elemen diterapkan dalam pemodelan. Tahap pemodelan struktur dilakukan untuk meninjau perilaku struktur serta mengontrol nilai deformasi struktur serta gaya-gaya dalam yang terjadi pada struktur. Pemodelan dilakukan dengan bantuan program MidasCIVIL.

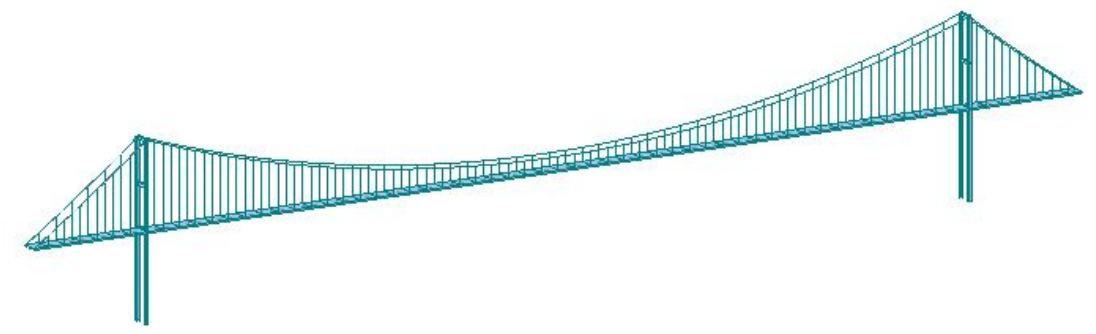

Gambar 3. Model 3D Jembatan Gantung

Variasi pembebanan yang diberikan pada struktur jembatan menggunakan prinsip checker board loading, sebagai berikut: 


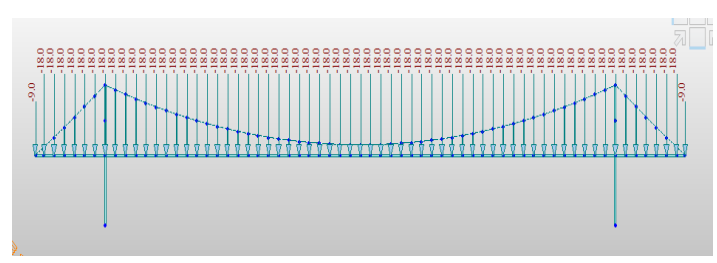

Gambar 4. Letak Pembebanan 1

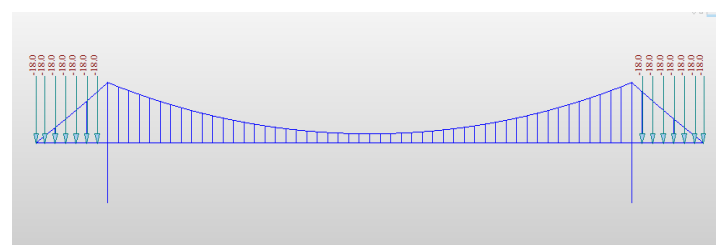

Gambar 6. Letak Pembebanan 3

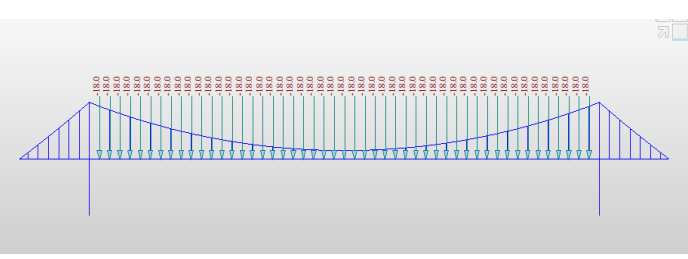

Gambar 5. Letak Pembebanan 2

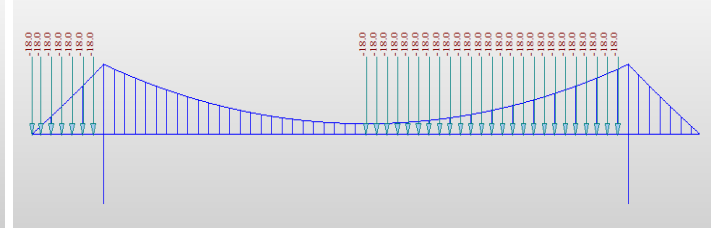

Gambar 7. Letak Pembebanan 4

\subsection{Penentuan Variasi Jenis Beban Aktual}

Variasi beban statis dihasilkan oleh beban hidup yang masuk ke jembatan gantung. Beban hidup yang diijinkan masuk ke jembatan pejalan kaki tipe I adalah pejalan kaki dan kendaraan bermotor roda dua. Kondisi pejalan kaki yang masuk ke jembatan gantung divariasikan berdasarkan bobot berat badan orang di Indonesia. Variasi ini dikelompokkan menjadi lima kelompok pejalan kaki dengan bobot masing-masing kelompoknya $60 \mathrm{~kg}, 70 \mathrm{~kg}, 80 \mathrm{~kg}, 90 \mathrm{~kg}$, dan $100 \mathrm{~kg}$.

Tabel 3. Pengelompokan Beban Pejalan Kaki Berdasarkan Bobot

\begin{tabular}{cc}
\hline Tipe Beban Pejalan Kaki & P total (kg) \\
\hline Orang 1 & 60 \\
\hline Orang 2 & 70 \\
\hline Orang 3 & 80 \\
\hline Orang 4 & 90 \\
\hline Orang 5 & 100 \\
\hline
\end{tabular}

Untuk variasi data kendaraan roda dua terdapat banyak sekali jenis dan merek kendaraan bermotor yang digunakan di Indonesia, maka pada penelitian ini kendaraan bermotor yang digunakan dibatasi hanya menggunakan 3 merek saja yaitu Suzuki, Honda dan Yamaha. Kendaraan bermotor dari tiga merek tersebut dikelompokan berdasarkan cc kendaraan nya. Sehingga diperoleh 4 pengelompokan kendaraan bermotor dengan masing-masing nilai cc sebesar $115 \mathrm{cc}, 125 \mathrm{cc}, 150 \mathrm{cc}$, dan $250 \mathrm{cc}$.

Dengan menganggap beban total $(\mathrm{P})$ pada kendaraan bermotor terbagi dua sama rata ke roda depan (P1) dan roda belakang (P2), maka pembagian variasi kendaraan bermotor dapat dilihat pada tabel berikut:

Tabel 4. Pengelompokan Berat Kendaraan Roda Dua

\begin{tabular}{lcccc}
\hline & cc & $\begin{array}{c}\text { P total } \\
(\mathbf{k g})\end{array}$ & P1 (kg) & P2 (kg) \\
\hline Motor 1 & 115 & 100.6 & 50.3 & 50.3 \\
\hline Motor 2 & 125 & 105.5 & 52.75 & 52.75 \\
\hline Motor 3 & 150 & 134.3 & 67.15 & 67.15 \\
\hline Motor 4 & 250 & 178.7 & 89.35 & 89.35 \\
\hline
\end{tabular}

Dari data pejalan kaki dan kendaraan roda dua di atas, tipe beban yang masuk ke struktur jembatan dapat divariasikan kembali, untuk kondisi hanya pejalan kaki saja yang masuk, maupun beban manusia masuk sebagai pengendara kendaraan roda dua. Untuk kondisi manusia sebagai pengendara 
roda dua, di asumsikan pengendara menjadi beban tambahan di roda depan dan penumpang menjadi beban di roda belakang. Kombinasi kendaraan roda dua dan variasi bobot pejalan kaki menghasilkan 80 kombinasi pembebanan yang kemudian diterapkan pada pemodelan sebagai 2 beban sumbu roda yang mengisi jembatan tersebut.

\subsection{Evaluasi keandalan jembatan terhadap variasi beban}

Tahapan ini akan menganalisis tegangan yang terjadi pada jembatan dari pemodelan akibat beberapa variasi beban pejalan kaki dan kendaraan roda 2. Elemen yang akan ditinjau adalah elemen batang penggantung jembatan, elemen kabel jembatan dan elemen pilar jembatan. Analisis ini akan mencakup nilai tegangan yang terjadi pada salah satu bagian dari elemen yang mengalami tegangan maksimum (ditinjau pada struktur global), dan dilakukan analisa statistika terhadap tegangan yang terjadi di bagian yang terpilih tersebut serta dilakukan pula analisa keandalan terhadap perilaku keseluruhan jembatan yaitu lendutan jembatan.

\section{HASIL DAN PEMBAHASAN}

\subsection{Luaran Pemodelan Struktur}

Hasil dari pemodelan yang telah dilakukan di atas adalah perilaku struktur baik secara keseluruhan maupun perilaku struktur pada kondisi elemental. Perilaku keseluruhan struktur yang ditinjau adalah nilai lendutan struktur secara keseluruhan sementara untuk kajian perilaku elemen struktur meninjau tegangan yang terjadi pada masing-masing elemen struktur dengan menggunakan beban sebesar $5 \mathrm{kPa}$ agar tidak melebihi nilai tegangan ijin.

Tabel 5. Perbandingan Tegangan Elemen dengan Tegangan Ijin

\begin{tabular}{llll}
\hline $\begin{array}{l}\text { Perilaku yang } \\
\text { Ditinjau }\end{array}$ & $\begin{array}{c}\text { Tahanan Elemen } \\
\text { Jembatan terhadap } \\
\text { Beban }\end{array}$ & $\begin{array}{c}\text { Kapasitas } \\
\text { Ijin }\end{array}$ & \multicolumn{1}{c}{ Keterangan } \\
\hline Lendutan & $433.63 \mathrm{~mm}$ & $500 \mathrm{~mm}$ & $\begin{array}{l}\text { Lendutan yang terjadi lebih kecil } \\
\text { dibandingkan lendutan ijin }\end{array}$ \\
\hline $\begin{array}{l}\text { Tegangan } \\
\text { Kabel }\end{array}$ & $167.41 \mathrm{MPa}$ & $372.96 \mathrm{MPa}$ & $\begin{array}{l}\text { Tegangan kabel yang terjadi lebih } \\
\text { kecil dibandingkan tegangan ijin }\end{array}$ \\
\hline $\begin{array}{l}\text { Tegangan } \\
\text { Batang } \\
\text { Penggantung }\end{array}$ & $172.93 \mathrm{MPa}$ & $200 \mathrm{MPa}$ & $\begin{array}{l}\text { Tegangan batang penggantung } \\
\text { yang terjadi lebih kecil } \\
\text { dibandingkan tegangan ijin baja } \\
\text { yang digunakan }\end{array}$ \\
\hline $\begin{array}{l}\text { Rasio } \\
\text { Kapasitas Pilar }\end{array}$ & $88.81 \mathrm{MPa}$ & $200 \mathrm{MPa}$ & $\begin{array}{l}\text { Tegangan pilar yang terjadi lebih } \\
\text { kecil dibandingkan tegangan ijin } \\
\text { tekan baja yang digunakan }\end{array}$ \\
\hline
\end{tabular}

\subsection{Analisis Keandalan Berdasarkan Variasi Beban}

Setelah dilakukan masukan variasi beban hidup statis dari kombinasi pejalan kaki dan kendaraan roda dua, respon struktur jembatan ditinjau pada tingkat struktur dan elemental seperti yang telah dilakukan dengan beban hidup merata sesuai peraturan sebesar $5 \mathrm{kPa}$. Hasil ini ditinjau pada elemen yang mengalami tegangan paling ekstrem. Selain meninjau tegangan yang terjadi pada elemen di atas ditinjau pula respon struktur dengan melihat lendutan yang terjadi pada struktur.

Nilai-nilai ini berupa variabel acak yang memiliki bentuk fungsi distribusi yang berbeda-beda. Dengan bantuan Easyfit, dilakukan penempatan nilai-nilai variabel acak luaran dari pemodelan ke fungsi distribusi (sumbu y menunjukkan nilai $\mathrm{f}(\mathrm{x})$ yaitu probabilitas terjadinya nilai fungsi, sementara sumbu $\mathrm{x}$ adalah nilai fungsi yang terjadi hasil luaran dari 80 variasi beban) sebagai berikut: 


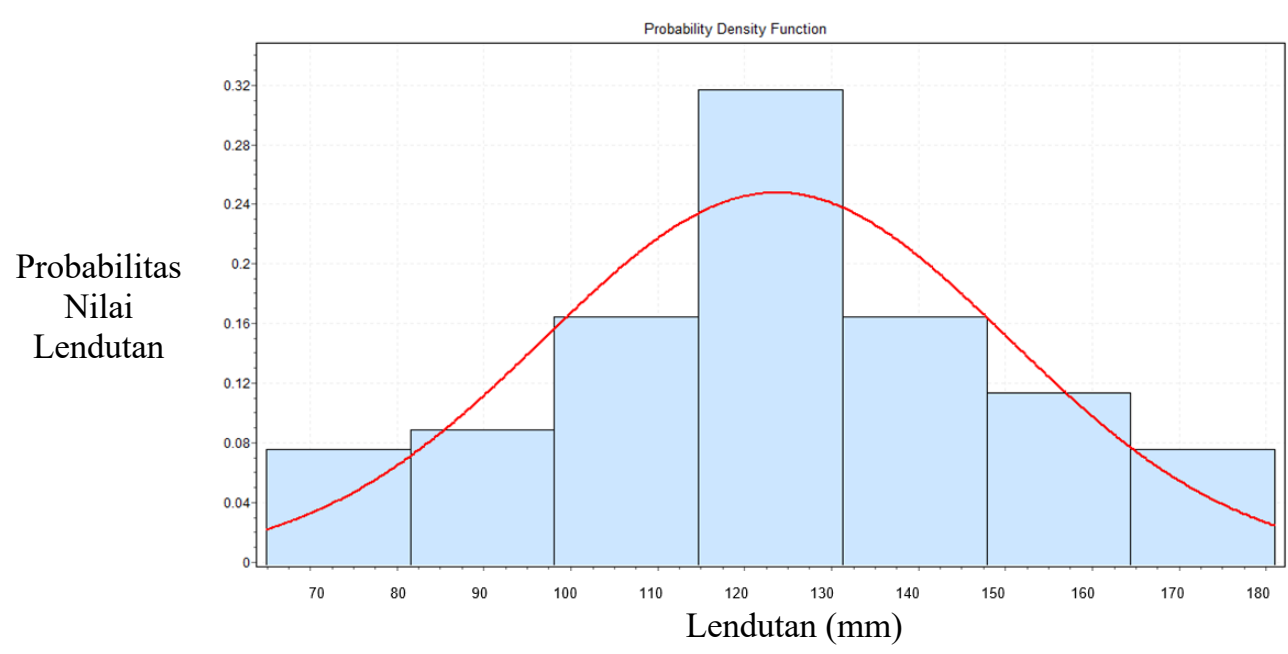

Gambar 8. Distribusi Fungsi Lendutan Berbentuk Distribusi Normal

(Nilai rata-rata: $124.54 \mathrm{~mm}$; Standar deviasi: $22.599 \mathrm{~mm}$ )

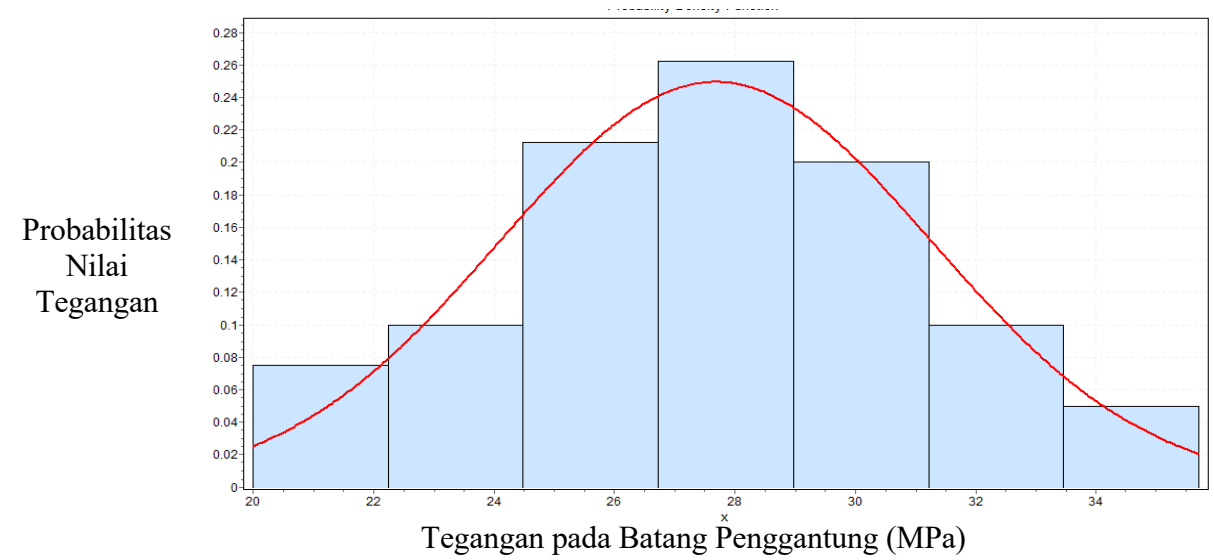

Gambar 9 Distribusi Fungsi Tegangan Batang Penggantung Berbentuk Distribusi Normal (Nilai rata-rata: $27.68 \mathrm{MPa}$; Standar deviasi: $0.29 \mathrm{MPa}$ )

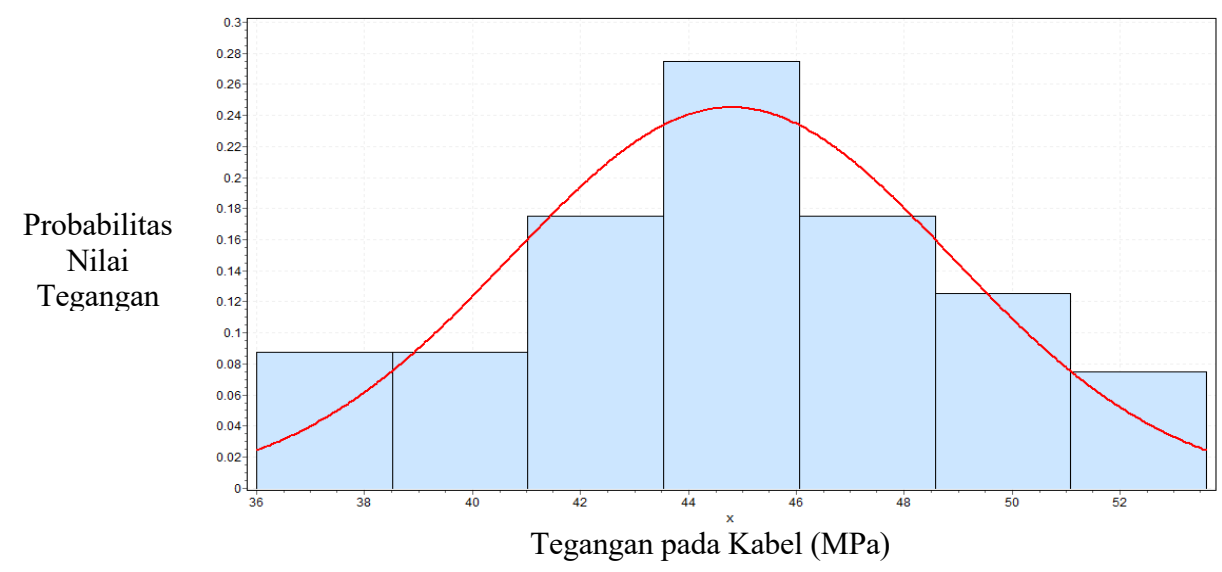

Gambar 10. Distribusi Fungsi Tegangan Kabel Berbentuk Distribusi Normal (Nilai rata-rata: $44.79 \mathrm{MPa}$; Standar deviasi: $4.09 \mathrm{MPa}$ ) 


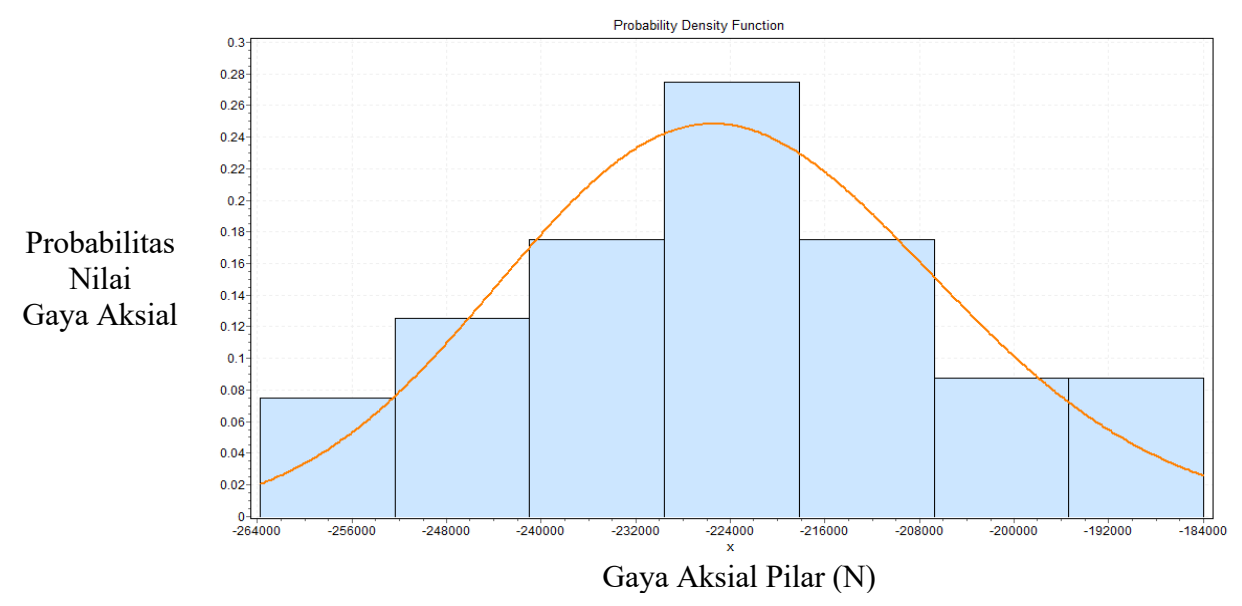

Gambar 11. Distribusi Fungsi Gaya Aksial Pilar Berbentuk Distribusi Log-Normal (Nilai rata-rata: $226.5 \mathrm{kN}$; Standar deviasi: $0.06 \mathrm{~N}$ )

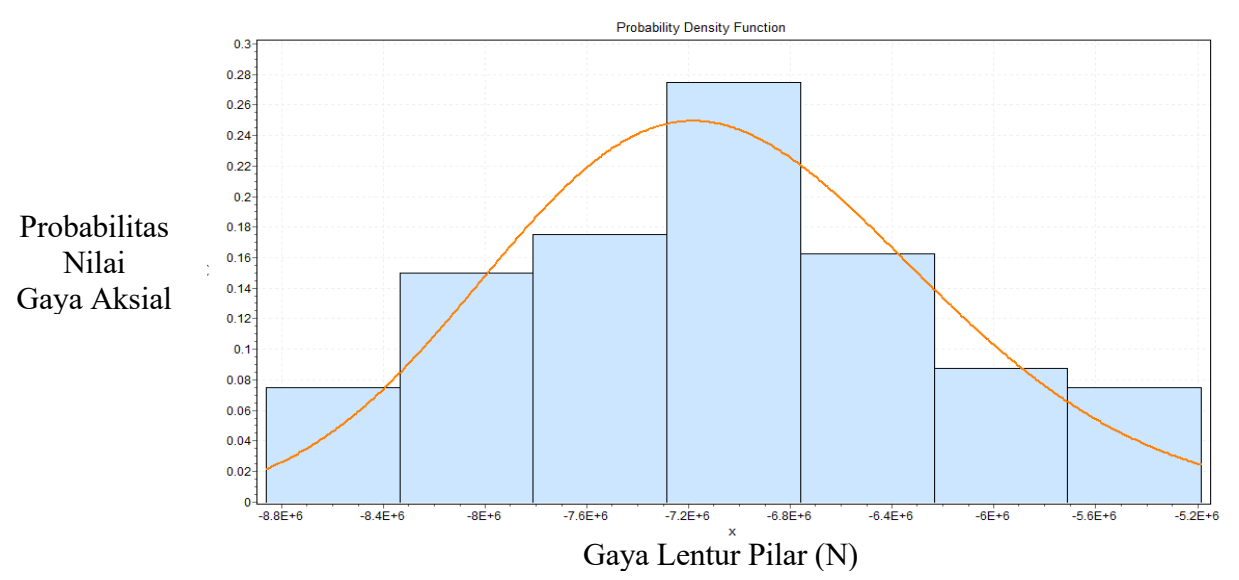

Gambar 12. Distribusi Fungsi Gaya Lentur Pilar Berbentuk Distribusi Log-Normal (Nilai rata-rata: $7.204 \mathrm{kNm}$; Standar deviasi: $0.09 \mathrm{Nmm}$ )

Perhitungan untuk tegangan batang penggantung dan kabel yang memiliki fungsi distribusi yang berbeda antara beban dan tegangan ijin, dimana fungsi perilaku beban memiliki bentuk normal sementara tegangan kapasitas material memiliki bentuk lognormal, dilakukan menggunakan direct integrase dengan rumus:

$$
\begin{gathered}
F x(y)=\Phi\left[\frac{\ln (y)-\lambda x}{\zeta x}\right] \\
f y(y)=\frac{1}{\sigma_{y} \sqrt{2 \pi}} \exp \left[-\frac{1}{2}\left(\frac{y-\mu_{y}}{\sigma_{y}}\right)\right] \\
P F=\int_{0}^{\infty} F x(y) \cdot f y(y)
\end{gathered}
$$

Menghitung peluang kegagalan dari batang penggantung:

$$
P F=\int_{0}^{\infty} \Phi\left[\frac{\ln (y)-5.516}{0.1}\right] \cdot \frac{1}{0.29 \sqrt{2 \pi}} \exp \left[-\frac{1}{2}\left(\frac{y-27.68}{0.29}\right)\right]
$$

Dihitung luasan dibawah kurva fungsi integral tersebut diperoleh $P F=0$. Dengan nilai peluang kegagalan di atas, maka keandalan struktur bernilai $100 \%$. 
Menghitung peluang kegagalan dari kabel:

$$
P F=\int_{0}^{\infty} \Phi\left[\frac{\ln (y)-6.209}{0.1}\right] \cdot \frac{1}{4.09 \sqrt{2 \pi}} \exp \left[-\frac{1}{2}\left(\frac{y-44.79}{4.09}\right)\right]
$$

Dihitung luasan dibawah kurva fungsi integral tersebut diperoleh $P F=0$. Dengan nilai peluang kegagalan di atas, maka keandalan struktur bernilai $100 \%$.

Sementara untuk batasan ijin dari lendutan bukanlah berupa fungsi, melainkan sebuah nilai yang disyaratkan dari peraturan sebesar $\frac{1}{200} \cdot 100 \mathrm{~m}=0.5 \mathrm{~m}=500 \mathrm{~mm}$. Sehingga perhitungan peluang kegagalan dilakukan sebagai berikut:

$$
\begin{gathered}
P F=1-\Phi\left[\frac{\mu_{R}-\mu_{L}}{\sqrt{\sigma_{R}^{2}+\sigma_{L}^{2}}}\right]=1-\Phi\left[\frac{500-124.54}{\sqrt{0^{2}+22.599^{2}}}\right] \\
\beta=16.61
\end{gathered}
$$

Sehingga

$P F=1-\Phi[16.61] \cong 0$

Dengan nilai peluang kegagalan mendekati 0 maka keandalan struktur ini pada tinjauan lendutan struktur sebesar $100 \%$.

Perhitungan peluang kegagalan pada elemen pilar memiliki dua kondisi keruntuhan yang dapat diwakilkan oleh suatu performance fuction:

$$
\frac{N}{A}+\frac{M \cdot y}{I}<\sigma
$$

Sehingga dari hasil plotting tegangan pada pilar yang memperoleh nilai gaya aksial dan lentur dalam fungsi lognormal, dikonversi ke nilai fungsi normal untuk dimasukan ke performance fuction bersamaan dengan luasan penampang pilar dan inersia.

$$
\begin{gathered}
\ln N=12.647 \rightarrow N=311059.814 \mathrm{~N} \\
\ln M=16.044 \rightarrow M=9287218.008 \mathrm{Nmm}
\end{gathered}
$$

Jika performance fuction tersebut diistilahkan dengan $g$, maka perhitungan peluang kegagalan pilar menjadi sebagai berikut:

$$
\begin{gathered}
g=\frac{N}{A}+\frac{M \cdot y}{\frac{l}{M} \cdot y}-\sigma \\
\bar{g}=\frac{\bar{M}}{A}+\frac{\bar{l}}{\frac{l}{M}}-\bar{\sigma} \\
\frac{311059.814}{11980}+\frac{9287218.008 \cdot 150}{204000000}-250=-217.206 \leq 0
\end{gathered}
$$

Diperoleh nilai hasil dari $g$ yang jauh nilainya dibawah 0 artinya struktur pilar yang direncanakan sangat aman untuk beban variasi kendaraan. Selanjutnya dilakukan perhitungan untuk mencari varian dari g.

$$
\begin{gathered}
\operatorname{var}[g]=\left(\frac{\partial g}{\partial N}\right)^{2} \cdot \operatorname{var}[N]+\left(\frac{\partial g}{\partial M}\right)^{2} \cdot \operatorname{var}[M]+\left(\frac{\partial g}{\partial \sigma}\right)^{2} \cdot \operatorname{var}[\sigma] \\
\frac{\partial g}{\partial N}=\frac{\partial\left(\frac{N}{A}+\frac{M \cdot y}{I}-\sigma\right)}{\partial N}=\frac{1}{A}=8.347 \cdot 10^{-5} \\
\frac{\partial g}{\partial M}=\frac{\partial\left(\frac{N}{A}+\frac{M \cdot y}{I}-\sigma\right)}{\partial M}=\frac{y}{I}=7.352 \cdot 10^{-7} \\
\operatorname{var}[g]=\left(8.347 \cdot 10^{-5}\right)^{2} \cdot 0.059+\left(7.352 \cdot 10^{-7}\right)^{2} \cdot 0.0911+(-1)^{2} \cdot 0.1 \\
\operatorname{var}[g]=0.1
\end{gathered}
$$


Karena bentuk fungsi distribusi gaya aksial dan lentur adalah lognormal, maka peluang kegagalan dihitung setelah nilai rata-rata $g$ dan variannya dikonversi kembali ke lognormal.

$$
\begin{gathered}
\zeta_{g}=\sqrt{\ln \left(1+(\operatorname{var}[g])^{2}\right)}=0.1 \\
\lambda_{g}=1-\ln (217.206)-0.5 \cdot 0.1^{2}=-5.375 \\
P F=\Phi\left[\frac{\ln 1-\lambda_{g}}{\zeta_{g}}\right]=\Phi(53.758)=0
\end{gathered}
$$

Sehingga nilai keandalan struktur sebesar $100 \%$.

\section{KESIMPULAN}

Berdasarkan hasil pembahasan mengenai keandalan dan probabilitas gagal pada penelitian yang telah dilakukan maka dapat diambil kesimpulan, setelah membandingkan hasil fungsi beban dari variasi beban terhadap kapasitas struktur, diperoleh nilai keandalan struktur sebesar $100 \%$ untuk elemen kabel dan mendekati $100 \%$ untuk elemen batang penggantung. Nilai keandalan struktur terhadap lendutan ijin pun memperoleh nilai mendekati $100 \%$. Sementara untuk elemen pilar, keandalan struktur dihitung menggunakan performance function. Hasil dari perhitungan keandalan pilar dengan tinjauan ini mendapatkan nilai keandalan struktur $100 \%$. Untuk perhitungan kriteria perilaku struktur keseluruhan dengan tinjauan lendutan struktur pun menghasilkan nilai keandalan $100 \%$. Artinya struktur kuat menahan variasi beban statis yang diberikan.

Hal tersebut menunjukkan bahwa nilai beban pada peraturan yang digunakan sebesar $5 \mathrm{kPa}$ menghasilkan peluang kegagalan yang sangat kecil dengan nilai tegangan akibat beban jauh lebih kecil dibandingkan dengan nilai kapasitas struktur. Sehingga dapat dilihat bahwa beban yang ditentukan pada peraturan bernilai cukup besar dibandingkan dengan beban aktual yang mungkin lewat pada jembatan. Oleh sebab itu nilai beban ini masih bisa direduksi untuk menghasilkan struktur jembatan yang lebih ekonomis.

\section{DAFTAR PUSTAKA}

[1] Ang, A.H-S., and Tang, W.H, (1984), Probability Concepts in Engineering Planning and Design Volume II - Decision, Risk, and Reliability, John Wiley and Sons, Inc., New York, United States.

[2] Departemen Pekerjaan Umum, (1994) “SNI 03-3428-1994" Tata Cara Perencanaan Teknik Jembatan Gantung Pejalan Kaki, Jakarta

[3] Dewobroto, W. (2005) Perkembangan Jembatan di Indonesia, Universitas Pelita Harapan. Karawaci, Indonesia

[4] Setiati, N.R. (2015). "Kekuatan Struktur Jembatan Gantung Sederhana untuk Pejalan Kaki." Jurnal: HPJI, Jakarta, Indonesia

[5] Surat Edaran Menteri Pekerjaan Umum No. 02/SE/M/2010, (2010), Pemberlakukan Pedoman Perencanaan dan Pelaksanaan Konstruksi Jembatan Gantung Untuk Pejalan Kaki, Kementerian Pekerjaan Umum. Jakarta, Indonesia

[6] Virlianda, T. (2018), Penanganan Vibrasi Jembatan Gantung Asimetris Dengan TMD Berdasarkan Kriteria Kenyamanan, Puslitbang Jalan dan Jembatan, Bandung, Indonesia 